\title{
Publisher Correction to: Swiss Journal of Palaeontology, vol 139
}

\author{
Swiss Journal of Palaeontology*
}

\section{Correction to: Swiss J Palaeontol (2020) 139 https://doi.org/10.1186/s13358-020-00207-7, https://doi.org/10.1186/s13358-020-00208-6}

Two articles (Klug et al. 2020; Lynch et al. 2020) in volume 139 of the Swiss Journal of Palaeontology published with an incorrect article number, this error was caused by a technical problem during publication. This Correction article is to publish the incorrect and correct article numbers.

The original publications have been updated to ensure correct attribution for future citations.

\section{Jaws of a large belemnite and an ammonite from the Aalenian (Middle Jurassic) of Switzerland (Klug et al. 2020)}

- Incorrect citation details: Klug, C., Etter, W., Hoffmann, R., et al. (2020). Jaws of a large belemnite and an ammonite from the Aalenian (Middle Jurassic) of Switzerland. Swiss Journal of Palaeontology, 139(4). https://doi.org/10.1186/s13358-020-00207-7.

- Correct citation details: Klug, C., Etter, W., Hoffmann, R., et al. (2020). Jaws of a large belemnite and an ammonite from the Aalenian (Middle Jurassic) of Switzerland. Swiss Journal of Palaeontology, 139(7). https://doi.org/10.1186/s13358-020-00207-7.

The original articles can be found online at https://doi.org/10.1186/s1335 8-020-00207-7 and https://doi.org/10.1186/s13358-020-00208-6.

*Correspondence: info@biomedcentral.com

London, UK

Full list of author information is available at the end of the article

\section{Description of a fossil camelid from the Pleistocene of Argentina, and a cladistic analysis of the Camelinae (Lynch et al. 2020)}

- Incorrect citation details: Lynch, S., Sánchez-Villagra, M. R., \& Balcarcel, A. (2020). Description of a fossil camelid from the Pleistocene of Argentina, and a cladistic analysis of the Camelinae. Swiss Journal of Palaeontology, 139(5). https://doi.org/10.1186/s1335 8-020-00208-6.

- Correct citation details: Lynch, S., Sánchez-Villagra, M. R., \& Balcarcel, A. (2020). Description of a fossil camelid from the Pleistocene of Argentina, and a cladistic analysis of the Camelinae. Swiss Journal of Palaeontology, 139(8). https://doi.org/10.1186/s1335 8-020-00208-6.

Author details

${ }^{1}$ London, UK.

Published online: 25 January 2021

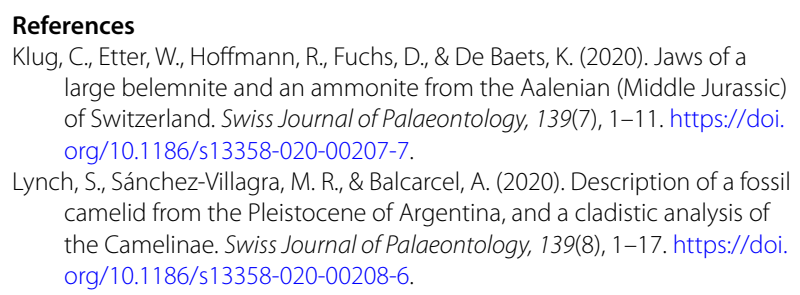

References large belemnite and an ammonite from the Aalenian (Middle Jurassic) of Switzerland. Swiss Journal of Palaeontology, 139(7), 1-11. https://doi. org/10.1186/s13358-020-00207-7.

camelid from the Pleistocene of Argentina, and a cladistic analysis of Camelinae. Swiss Journal of Palaeontology, 139(8), 1-17. https://doi. 